\title{
A NEW AsterINA SPECIES FROM KERALA, INDIA
}

\section{V.B. Hosagoudar}

Microbiology Division, Tropical Botanic Garden and Research Institute, Palode 695 562, Thiruvananthapuram, Kerala, India Email: hosagoudar@hotmail.com

\section{Abstract \\ A new species of the genus Asterina has been described and illustrated in detail from Kerala \\ KEYWORDS \\ Asterina phyllanthigena, fungi, new species, Kerala, India}

During a survey of the foliicolous micromycetes in the Western Ghats region of Kerala State, a shrubby Phyllanthus plant, bearing edible fruits, was found infected with a black mildew disease. Microscopic details revealed that it was an undescribed species of the genus Asterina. Hence the note.

\section{Material examined}

Asterina phyllanthigena sp. nov.

Type: 27.xii.2001, Sankili forest, Kollam, Kerala, coll. V.B. Hosagoudar, on leaves of Phyllanthus sp. (Euphorbiaceae), HCIO 42888.

Isotype: TBGT 206.

\section{Diagnosis}

Coloniae epiphyllae, tenues vel subdensae, ad $1 \mathrm{~mm}$ diam., confluentes. Hyphae flexuosae, formis laxe reticulatae, cellulae 16-20x3-4um. Appressoria pauca, dispersa, bicellula, recta vel curvula, 9-11 $\mu$ m longa; cellulae basilares cylindraceae vel cuneatae, 2-3 $\mu$ m longae; cellulae apicales ovatae vel oblongae, ad apicem leniter attenuatae vel late rotundatae, integrae, 4-6x4-5 $\mu \mathrm{m}$. Thyriothecia dispersa, orbicularis, ad $80 \mu \mathrm{m}$ diam., stellato dehiscentes ad centrum, margine crenatae; asci pauci, globosi, octospori, ad $30 \mu \mathrm{m}$ diam.; ascosporae oblongae, conglobatae, brunneae, uniseptatae, leniter constrictae, 12-14x6-8um, parietus glabrus. Pycnothyria thyriotheciis similis, breviter; pycnothyriosporae oblongae vel piriformis, apiculatae,

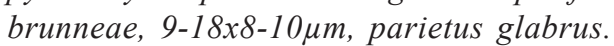

Colonies epiphyllous, thin to subdense, up to $1 \mathrm{~mm}$ in diameter, confluent. Hyphae flexuous, form a loose net of hyphae, cells $16-20 \times 3-4 \mu \mathrm{m}$. Appressoria few, scattered, two-celled, straight to curved, $9-11 \mu \mathrm{m}$ long; stalk cells cylindrical to cuneate, $2-$ $3 \mu \mathrm{m}$ long; head cells ovate to oblong, slightly attenuated and

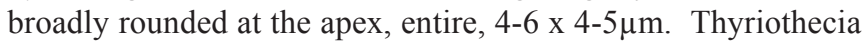
scattered, orbicular, up to $80 \mu \mathrm{m}$ in diameter, stellately dehisced at the centre, margin crenate; asci few, globose, octosporous, up to $30 \mu \mathrm{m}$ in diameter; ascospores oblong, conglobate, brown, uniseptate, slightly constricted, $12-14 \times 6-8 \mu \mathrm{m}$, wall smooth. Pycnothyria similar to thyriothecia, smaller; pycnothyriospores

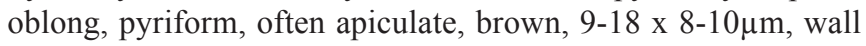
smooth.

\section{Remarks}

Asterina phyllanthicola Singh is known on the genus Phyllanthus from the Himalayan region of Uttar Pradesh (Hosagoudar \& Abraham, 2001; Singh, 1980). However, A. phyllanthigena differs from it in having loosely net forming hyphae, remotely placed shorter appressoria and smaller ascospores.

\section{REFERENCES}

Hosagoudar, V.B. and T.K. Abraham (2000). A list of Asterina Lev. species based on the literature. Journal of Economic and Taxonomic Botany 24: 557-587.

Singh, S. (1980). Asterina phyllanthicola sp. nov. from India. Transactions of the British Mycological Society 74: 204-205.

\section{ACKNOWLEDGEMENT}

Thanks are due to Dr. G.M. Nair, Director, TBGRI, Palode for the facilities.
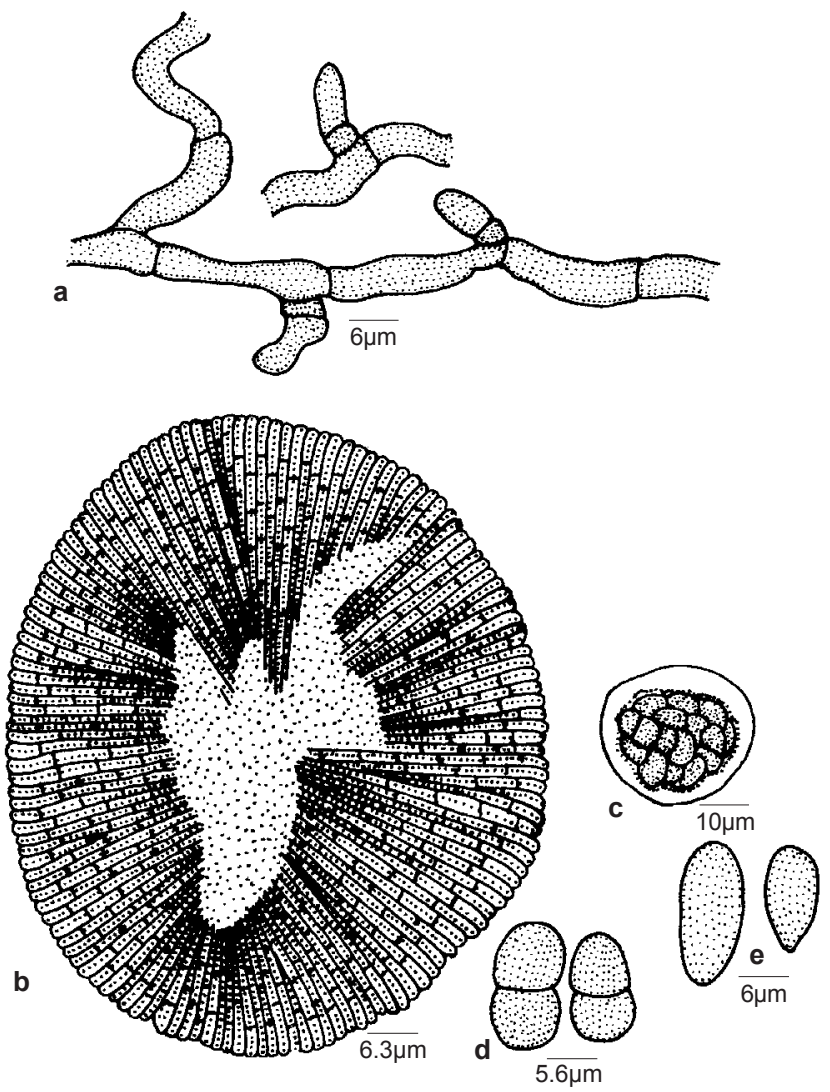

Asterina phyllanthigena sp. nov.

a - Appressoriate mycelium; b - Thyriothecium; c - Ascus; d - Ascospores; e - Pycnothyriospores 